\title{
Auto-reactive B cells in MuSK myasthenia gravis
}

\author{
Yoon-Ho Hong', Jung-Joon Sung ${ }^{2}$ \\ ${ }^{1}$ Department of Neurology, Seoul National University College of Medicine, Seoul Boramae Medical Center, Seoul 07061, South Korea. \\ ${ }^{2}$ Department of Neurology, Seoul National University College of Medicine, Seoul National University Hospital, Seoul 03080, South Korea.
}

Correspondence to: Prof. Jung-Joon Sung, Department of Neurology, Seoul National University College of Medicine, Seoul National University Hospital, Seoul 03080, South Korea. E-mail: jjsant@snu.ac.kr

How to cite this article: Hong YH, Sung JJ. Auto-reactive B cells in MuSK myasthenia gravis. Neuroimmunol Neuroinflammation 2016;3:196-7.

Article history: Received: 22-05-2016 Accepted: 04-07-2016 Published: 31-08-2016

On [Guptill JT, Yi JS, Sanders DB, Guidon AC, Juel VC, Massey JM, Howard JF Jr, Scuderi F, Bartoccioni E, Evoli A, Weinhold KJ. Characterization of B cells in muscle-specific kinase antibody myasthenia gravis. Neurol Neuroimmunol Neuroinflamm 2015;2:e77]

Acquired myasthenia gravis (MG) is a protoypical autoimmune disease caused by a dysfunction of neuromuscular transmission at the postsynaptic part. Patients experience fluctuating muscle weakness that increases with exertion. It is typically classified into clinical subtypes depending on distribution of involved muscles, onset age, thymic pathology, and auto-antibodies. While the most common autoantibodies are targeted towards the skeletal muscle acetylcholine receptor (AChR), the list of target molecules of pathogenic auto-antibodies has been expanding to include the muscle specific tyrosine kinase (MuSK), low-density lipoprotein receptorrelated protein 4 and agrin..$^{[1-5]}$

MuSK MG in particular has been of great interest. It is clinically characterized by bulbar predominant manifestation, marked atrophy of the involved facial muscle, frequent myathenic crisis, poor outcome with conventional immunosuppressants, intolerance to acetylcholinesterase inhibitors, and fewer thymic pathologic changes. ${ }^{[6]}$ The disease is also known for its unique immunological features. The pathogenic autoantibodies are mainly immunoglobulin G4 $(\operatorname{lgG} 4),{ }^{[7]}$ which unlike the $\lg$ subtypes in AChR MG (IgG1 and IgG3) does not activate the complements and effector cells. Little is known about the precise cellular components and molecular mechanisms in MuSK MG.

Guptill et al. ${ }^{[8]}$ have recently reported the characteristics of B lymphocytes in MuSK MG patients. They performed polychromatic flow cytometry and enzymelinked immuno sorbent assays in peripheral blood samples from MuSK MG patients, and compared immunological features of the patients to those of healthy controls. They found no differences in the frequencies of total $B$ cells and $B$ cell subsets (naive, memory, class-switched, plasmablasts and transitional cells) between the healthy controls and MuSK MG patients who had not been treated with rituximab (anti-CD20 monoclonal antibody). There

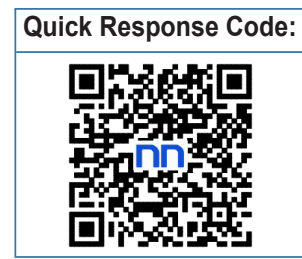


was no difference between immunosuppressed and non-immunosuppressed patients either. However, the plasma B-cell activating factor (BAFF) levels were significantly increased in MuSK MG patients; another main finding of this study is that in vitro stimulation of peripheral blood mononuclear cells resulted in lower percentages of B10 cells in MuSK MG patients compared to controls.

Despite the limitations of small number of patients and heterogeneous treatments, this study provides novel insights and understanding of the immunopathology of MuSK MG. First, this study supports the emerging pathogenic role of BAFF which is a cytokine essential for the survival and differentiation of $B$ cells. A clinical trial of belimumab, the monoclonal antibody that targets BAFF, is currently in progress for MG patients. It will be interesting to see if the drug is effective for MuSK MG which is often refractory to conventional immunosuppressive treatment. Second, B10 cells are recently characterized regulatory subset of $B$ cells producing IL-10. With no change in Treg frequency and function, the reduced B10 cells observed in this study suggests a potential mechanism of breakdown in the immune tolerance in MuSK MG. ${ }^{[0]}$ Future studies of larger number of patients would help further elucidate the precise immunobiology of this rare autoimmune disease.

\section{Financial support and sponsorship}

Nil.

\section{Conflicts of interest}

There are no conflicts of interest.

Patient consent

No patient involved.

\section{Ethics approval}

This article does not contain any studies with human participants or animals.

\section{REFERENCES}

1. Hoch W, McConville J, Helms S, Newsom-Davis J, Melms A, Vincent A. Auto-antibodies to the receptor tyrosine kinase MuSK in patients with myasthenia gravis without acetylcholine receptor antibodies. Nat Med 2001;7:365-8.

2. Higuchi O, Hamuro J, Motomura M, Yamanashi Y. Autoantibodies to low-density lipoprotein receptor-related protein 4 in myasthenia gravis. Ann Neurol 2011;69:418-22.

3. Zhang B, Tzartos JS, Belimezi M, Ragheb S, Bealmear B, Lewis RA, Xiong WC, Lisak RP, Tzartos SJ, Mei L. Autoantibodies to lipoproteinrelated protein 4 in patients with double-seronegative myasthenia gravis. Arch Neurol 2012;69:445-51.

4. Pevzner A, Schoser B, Peters K, Cosma NC, Karakatsani A, Schalke B, Melms A, Kröger S. Anti-LRP4 autoantibodies in AChR- and MuSKantibody-negative myasthenia gravis. J Neurol 2012;259:427-35.

5. Zhang B, Shen C, Bealmear B, Ragheb S, Xiong WC, Lewis RA, Lisak RP, Mei L. Autoantibodies to agrin in myasthenia gravis patients. PLoS One 2014;9:e91816.

6. Oh SJ. Muscle-specific receptor tyrosine kinase antibody positive myasthenia gravis current status. J Clin Neurol 2009;5:53-64.

7. Klooster R, Plomp JJ, Huijbers MG, Niks EH, Straasheijm KR, Detmers FJ, Hermans PW, Sleijpen K, Verrips A, Losen M, MartinezMartinez P, De Baets MH, van der Maarel SM, Verschuuren JJ. Musclespecific kinase myasthenia gravis IgG4 autoantibodies cause severe neuromuscular junction dysfunction in mice. Brain 2012;135:1081-101.

8. Guptill JT, Yi JS, Sanders DB, Guidon AC, Juel VC, Massey JM, Howard JF Jr, Scuderi F, Bartoccioni E, Evoli A, Weinhold KJ. Characterization of B cells in muscle-specific kinase antibody myasthenia gravis. Neurol Neuroimmunol Neuroinflamm 2015;2:e77.

9. Yi JS, Guidon A, Sparks S, Osborne R, Juel VC, Massey JM, Sanders DB, Weinhold KJ, Guptill JT. Characterization of CD4 and CD8 T cell responses in MuSK myasthenia gravis. J Autoimmun 2014;52:130-8. 